\title{
Feasibility Assessment of Sugarcane Expansion in Southwest Goiás, Brazil Based on the GIS Technology
}

\author{
Bruno Cardoso Pedrosa1, Tuani Cristine Lima de Souza², Ana Paula Dias Turetta ${ }^{3}$, \\ Heitor Luis da Costa Coutinho ${ }^{3^{*}}$ \\ ${ }^{1}$ Department of Environmental Engineering of Pontifícia Universidade Católica of Rio de Janeiro, Rio de Janeiro, \\ Brazil \\ ${ }^{2}$ Department of Geography of Rio de Janeiro Federal University, Rio de Janeiro, Brazil \\ ${ }^{3}$ Brazilian Agricultural Research Corporation, Nacional Center for Soil Research (EMBRAPA Soils), Rio de Janeiro, \\ Brazil \\ Email: cpedrosabruno@gmail.com, tuanirosa@hotmail.com, ana.turetta@embrapa.br
}

Received 11 February 2016; accepted 28 March 2016; published 31 March 2016

Copyright (C) 2016 by authors and Scientific Research Publishing Inc.

This work is licensed under the Creative Commons Attribution International License (CC BY). http://creativecommons.org/licenses/by/4.0/

(c) (7) Open Access

\begin{abstract}
The current study approaches the sugarcane culture expansion in Southwestern Goiás, especially in Mineiros, Quirinópolis and Rio Verde counties, which represent different times and responses to this process. The current logistics structure and future prospects for sugarcane and its derivatives transportation are studied at national level with emphasis to the aforementioned micro-region. Maps showing land use and land cover in three different years were generated from Landsat TM-5 satellite images and they were used to analyze the dynamics of changes in land use and in land cover. The region is marked by strong and rapid growth in the agricultural sector and its sugar-energy industry has been expanding in recent years, although with different aspects among its counties. Since it is a promising region in this sector, due to the favorable soil and weather conditions to the crop, the region requires more investment and planning in logistics to ensure production flow and to make it stronger within domestic and foreign markets.
\end{abstract}

\section{Keywords}

GIS, Land Use and Land Cover, Sugarcane Expansion, Sustainability

\section{Introduction}

The agricultural frontier expansion into the Brazilian Midwestern region happened mostly from the 1970s, in the *In memoriam.

How to cite this paper: Pedrosa, B.C., de Souza, T.C.L., Turetta, A.P.D. and da Costa Coutinho, H.L. (2016) Feasibility Assessment of Sugarcane Expansion in Southwest Goiás, Brazil Based on the GIS Technology. Journal of Geographic Information System, 8, 149-162. http://dx.doi.org/10.4236/igis.2016.82014 
period known as "Green Revolution"-induced Agricultural Modernization. It deeply changed the Brazilian agriculture by promoting new perspectives in the production relationships within the agrarian space [1].

The sugar-alcohol industry went through several stages in Brazil, but the sugarcane production was almost consolidated in the Southeastern region of the country, especially in São Paulo State [2]. Nowadays, one of the preferred areas to expand this culture was the Midwestern region, where it was already possible to see a large concentration of old and new ethanol plants, especially in the Central and Southern regions of Goiás State, whose growth started in 2005 [3] [4].

Southern Goiás hosts most of the plants and planting areas found in the State-especially on soft ground covered by clayey and deep soils such as Red Latosols—and one of its micro-regions, Quirinópolis, has become the new production center [5] since sugarcane arrival in 2004. Despite having the same type of soil and relief, other counties such as Rio Verde are not being targeted by the expansion because they are consolidated into other agro-industrial sectors such as grains and livestock. Finally, counties-such as Mineiros-showing smooth relief, but low performance sandy soils—such as Quartzipsamments—started planting sugarcane since 2008 [5].

The intense change dynamics in land use and in land cover in Southwestern Goiás requires studies that allow monitoring this evolution, since these studies are able to identify factors that could put the dynamic equilibrium of the territory and of its landscapes at risk. This identification could be done by surveying the areas' capabilities and vulnerabilities through satellite imagery, since it allows estimating cultivated and deforested areas, among others [6].

\section{Research Questions}

\subsection{Current Panorama of the Sugar-Energy Industry}

According to extensive literature on the subject, sugarcane was introduced in the country at the beginning of the sixteenth century. It was of great economic importance in colonial Brazil and it was mainly concentrated in the Northeastern region. In the 1970s, Brazil included the Alcohol Program (PROÁLCOOL) in its Second National Development Plan (1975-79) due to the first major contemporary oil crisis. It was done in order to replace petroleum as fuel; thus, Brazil subsidized the development of alcohol-powered cars. The effects of this program extended up to the first half of the following decade when the government subsidies ceased to occur. Consequently, the sector fell into crisis and underwent a relative stagnation process that continued into the 1990s.

Since the end of the1990s, sugarcane became again the center of attention as the ethanol production basis in Brazil due to the environmental crisis that induced a growing market for bioenergy, since ethanol was said to be a source cleaner than oil derivatives [2]. According to the National Agency of Petroleum, Natural Gas and Biofuels [7], biofuels are renewable biomass-derived fuels that may partially or fully replace oil and natural gas derivatives in combustion engines or in other power generation type processes and ethanol is an example of them. According to UNICA [8] [9], approximately $45 \%$ of the energy and $18 \%$ of the fuel consumed in Brazil are already renewable. Elsewhere in the world, $86 \%$ of the energy comes from non-renewable energy sources. Figure 1 depicts the sugarcane production in the country since 1970, the vicissitudes resulting from Proálcool and the crisis in the sector. However, it is possible to see an exponential growth since 2000.

Nowadays, the technological research and development in the industry allow stating that, in addition to sugar and ethanol, which are still the two main products in the sugar-alcohol industry, there is a variety of products generated in the sugarcane production chain. It shows the new alternatives to increase the sector's revenue by using sugarcane by-products in other sectors. Figure 2 illustrates this productive diversity in the sugarcane agro-industrial system. However, since many products are generated with different demands and production volumes, it is necessary to conduct studies on the logistics of each product's production system.

According to the Agricultural Production Systematic Survey prepared by the Brazilian Institute of Geography and Statistics [10], the sector is currently the 3rd largest producer in the Brazilian agribusiness, just losing to soybeans and corn production. The institute estimated the production of over 700 million tons of sugarcane in the 2013 season, which repeated the 2011 production after a small decline in 2012 (Figure 3). According to the production trend, productivity has also increased due to improvements done in farming and logistics techniques.

\subsection{Ethanol}

Ethanol is one of the sugarcane derivatives that show increased demand and production, and it is one of the pil- 


\section{Sugarcane Production in Brazil}

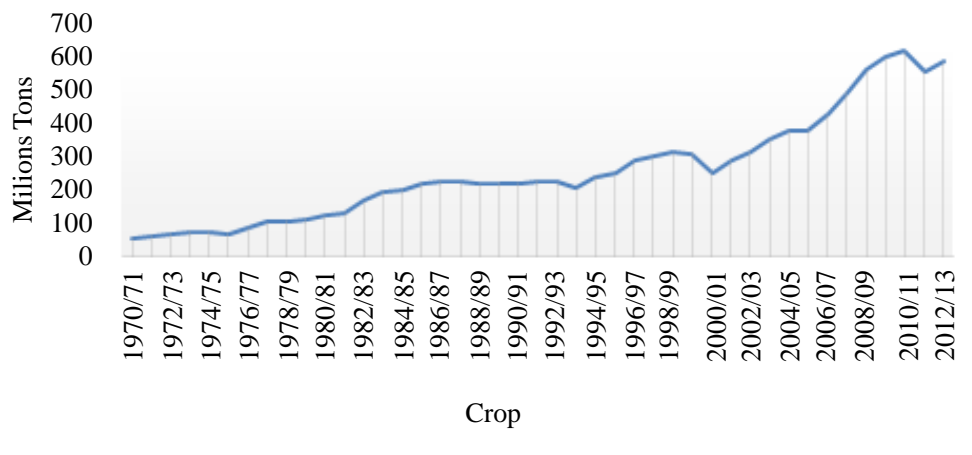

Figure 1. Sugarcane production in Brazil. Source: MAPA/UNICA [8] [11].

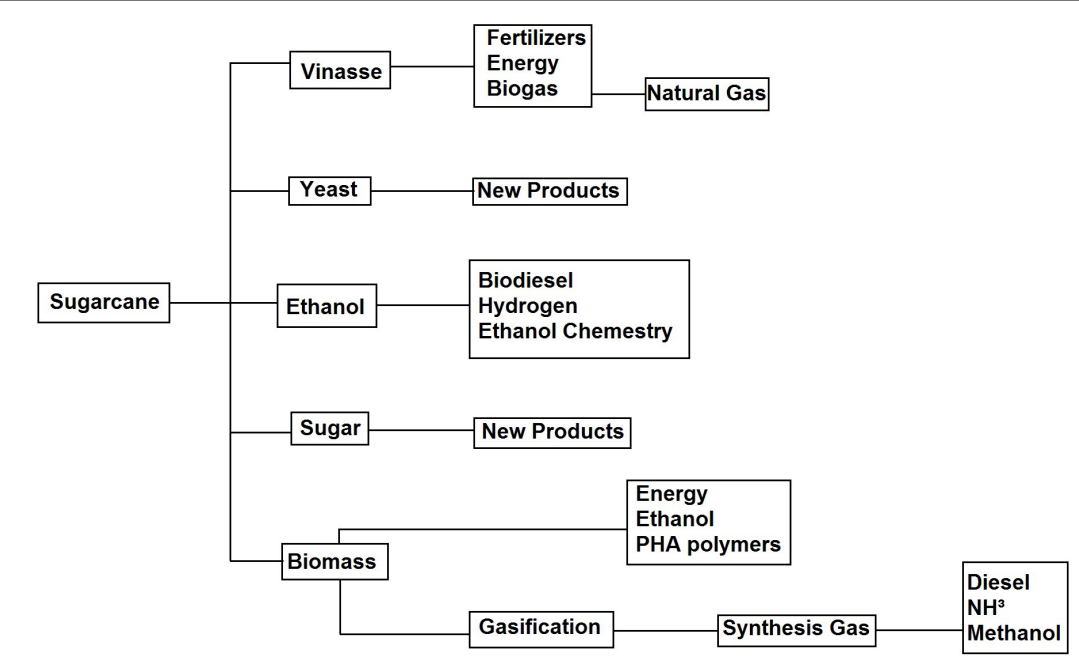

Figure 2. Sugarcane derivatives. Source: IBGE [10].

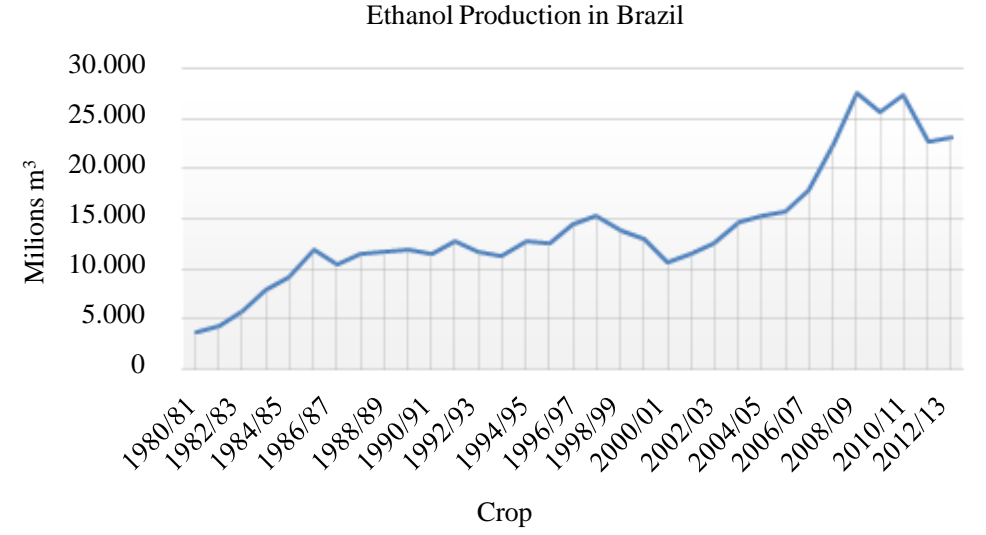

Figure 3. Ethanol production in Brazil. Source: UNICA [8]. 
lars of the sugarcane agribusiness system. Brazil is the largest biofuel producer and one of the major exporters in the world. Nowadays, the gasoline used as vehicle fuel has $25 \%$ anhydrous ethanol (suitable for mixing), fact that creates one of the largest demands for alcohol. Therefore, the Brazilian automobile industry production directly affects ethanol production and distribution.

Ethanol production is also directly related to the production of dual-fuel vehicles that use both gasoline and alcohol, at any ratio, in the same tank and influence the biofuel market (Figure 4).

The product has higher specificity than the other sugarcane derivatives in terms of transport, i.e., it requires suitable equipment and techniques to be transported. Its distribution is primarily done by means of highways, and it increases the export price in comparison to the ethanol produced in São Paulo, since the distance from the Midwestern region to the ports on the coast shore is significantly longer.

\subsection{Sugar}

Sugar is one of the most important and old products in the sugarcane agro-industrial chain. The country leads sugar production and export, thus it dominates the world market. It has increased its production in recent years and its participation in the international market is increasingly important (Figure 5).

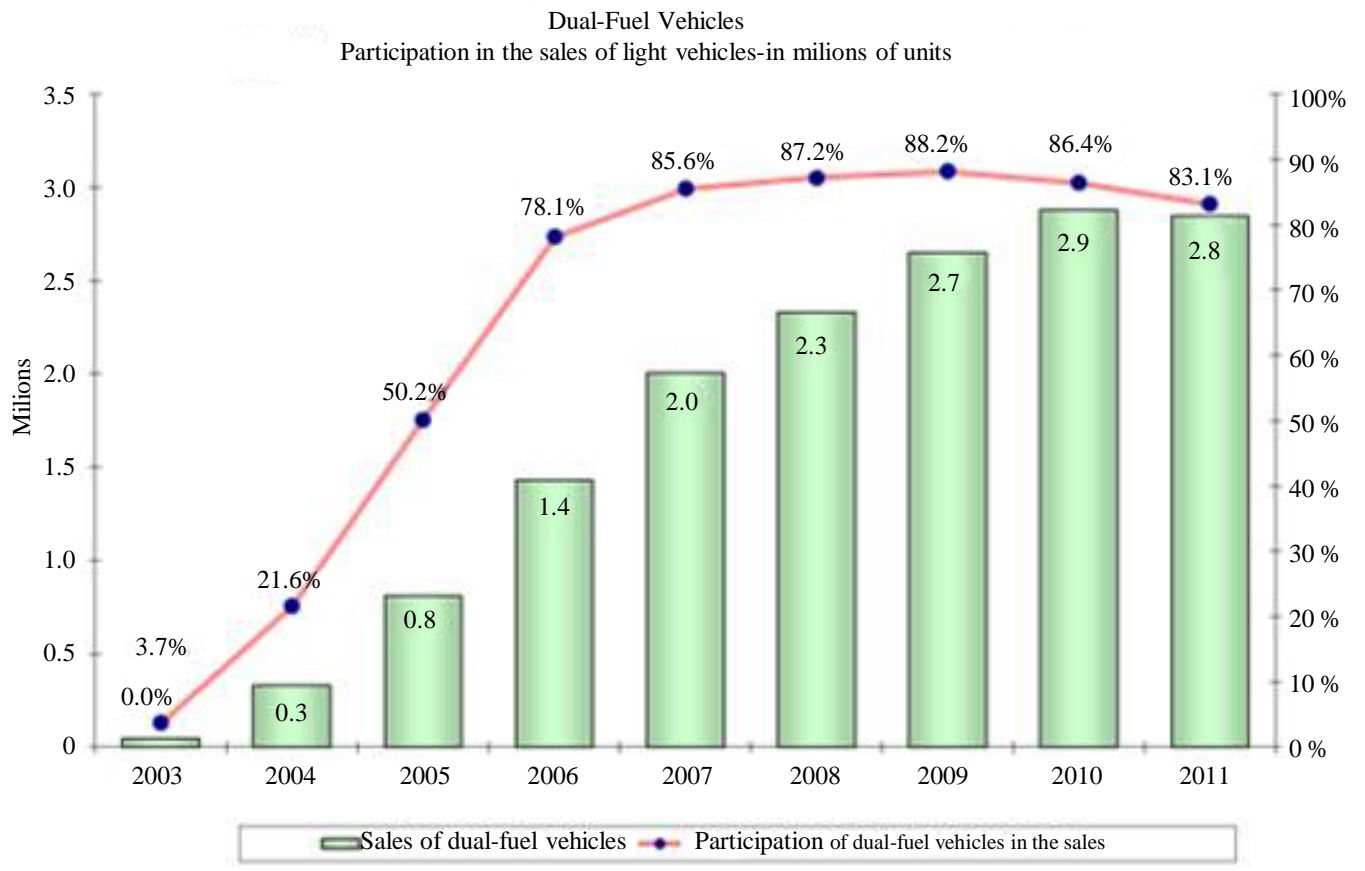

Figure 4. Participation in sales of dual-fuel vehicles. Source: MDIC [12].

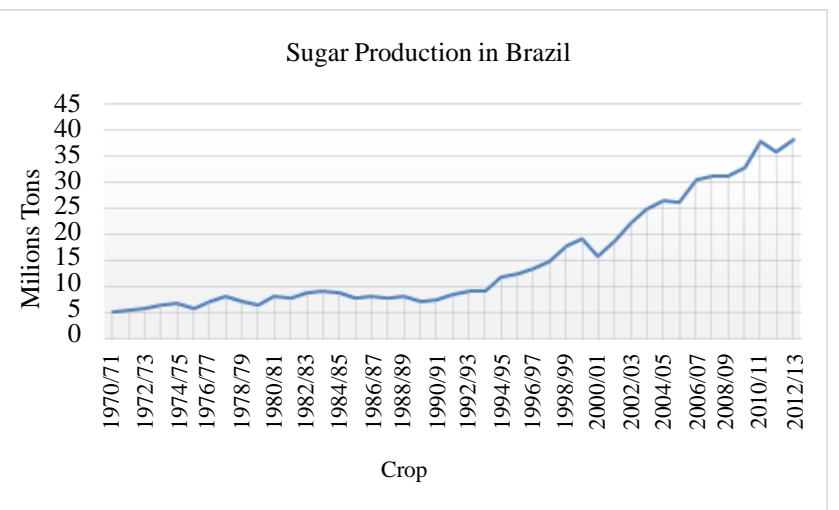

Figure 5. Sugar production in Brazil. Source: UNICA/MAPA [8] [11]. 
Since both sugar and ethanol are produced out of the same raw material, their production is dictated by their respective markets. According to UNICA, approximately $40 \%$ of the sugarcane supply is currently destined to sugar mills, whereas $60 \%$ is directed to ethanol production, thus explaining the current biofuel panorama.

\subsection{The Sugarcane Logistics}

As in any agro-industrial system, the storage and transportation logistics of the sugar-energy industry production is a factor of great specificity and it presents features inherent to each product type. Logistics becomes an important study object in order to find a way to minimize costs and to make the chain more competitive as a whole, by knowing each condition [13].

Logistics is simply structurally composed of two groups, namely: transportation and storage. Transportation is an operation that moves the product from its source to the destination [14]. On the other hand, storage is an important stage in business planning, since the market demand is stable throughout the year-unlike the supply-due to production seasonality. Therefore, the production needs to be stored and transported according to the market demand in order to meet the compatibility between demand and supply [15]. The specificities of each product as well as the available infrastructure must be known in order to provide proper transport logistics [16]. The modes used to transport sugarcane and its derivatives in Brazil are railroads, waterways, highways and pipelines.

The railways also present many constraints such as the difference between gauges in different sections, the small number of dealers and the difficulty in negotiating freight, in addition to the specificity of the equipment used to transport ethanol, which limits its transport capacity. On the other hand, the railway transportation freight is approximately $25 \%$ cheaper than the road freight. In addition, it emits four times less CO2 into the atmosphere [17].

Nowadays, the waterways are not used to transport ethanol for environmental reasons, and they are limited to transport sugar and sugarcane. This mode presents the cheapest freight; however, it consumes a lot of time and is inflexible. Attention should be paid to the transportation time length since sugarcane chemical features change over time. The region hosts the Paraná-Tietê waterway, which may be an excellent route to transport the production from the Midwestern region to ports and markets in the Southeastern region [18] [19]. There is also concern about weather events such as long periods of drought, which may turn the waterway unnavigable until its water level is reestablished.

The road transportation is the most used in the Brazilian matrix and it has 90,000 kilometers of federal and state highways [20]. The quality of the roads is an important point, because they are not always found in proper condition. Although it is more expensive and polluting in comparison to the previous modes, it is the most reliable and negotiable for the producer, since there is great supply in the region and it is not so vulnerable to natural events. The Brazilian government started the Logistics Investment Program (PIL-Programa de InvestimentosemLogística), which deals with federal highway concessions to private companies-many of them located in the Center-South axis of the country-in order to improve transportation conditions in strategic routes (Figure 6).

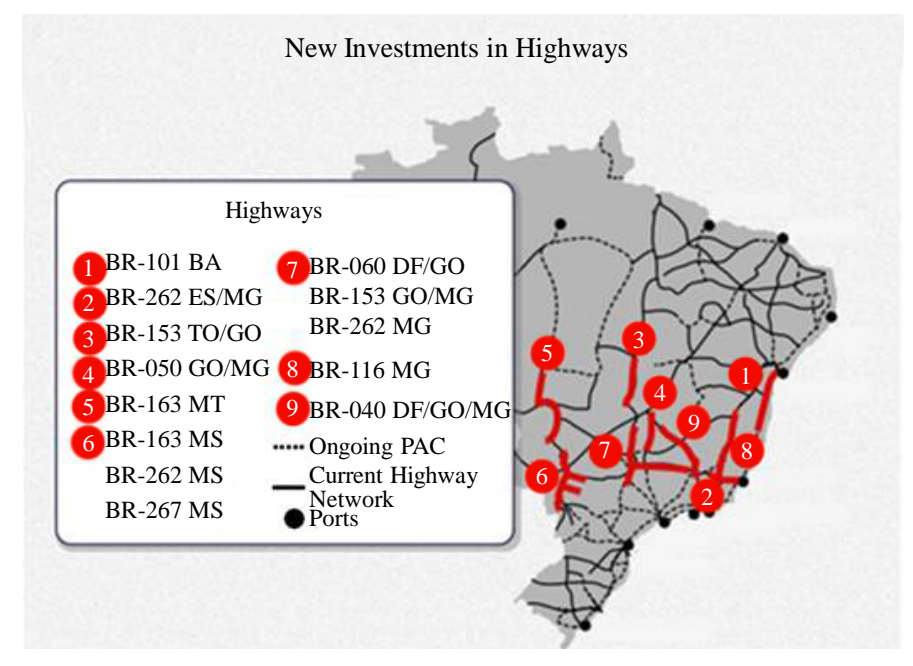

Figure 6. Logistics investment plan (PIL)—highways. Source: MT [20]. 
Another sector that receives major investments is the pipeline transportation mode, which is dedicated to ethanol transportation. The project was launched in 2010 and it aims to connect 45 counties in the States of Goiás, Mato Grosso doSul, Minas Gerais and São Paulo. It has the capacity to transport 20 million cubic meters of ethanol per year, according to the government (Figure 7).

These new projects will provide more alternatives with lower costs and environmental impacts on the transportation and on the market supply by improving the current production flow dynamics.

\subsection{Southwestern Goiás and the Expansion of Sugarcane Cultivation}

The Southwestern region of Goiás State is the area investigated in the current study, more specifically in Mineiros, Rio Verde and Quirinópolis counties. These counties provide good soil and topographical conditions for the overall agriculture and they have adequate infrastructure. The good availability of sugar and ethanol refining plants is also attractive to sugarcane production, which, despite the long distance from the Southeastern ports, is well located to supply the Brazilian internal market and is very close to transportation modes, including pipelines [21] (Figure 7).

It is possible to see the great expansion of the agricultural sector in the region in a short time, especially in the area cultivated with sugarcane [22]. The participation of these three counties in the sugarcane production in Southwestern Goiás has remarkably increased in recent years, thus showing the important role they play in the Southwestern region of Goiás State (Figure 8).

\section{Material and Methods}

The current study approached the Southwestern region of Goiás State proposed by the Goiás State Planning Department. It covers an area of approximately $61,498 \mathrm{~km}^{2}$ and comprises 26 counties, according to SEINFRA [20].

Satellite images from Landsat TM-5 were selected. The images are available on the National Spatial Research Institute (INPE-Instituto Nacional de PesquisasEspaciais) homepage (http://www.dgi.inpe.br/CDSR/) and they corresponded to the following years: 1985 (before the recent expansion), 2004 (beginning of the recent expansion) and 2010 or 2011 (consolidated expansion). The image selection criteria were: variety of available images,

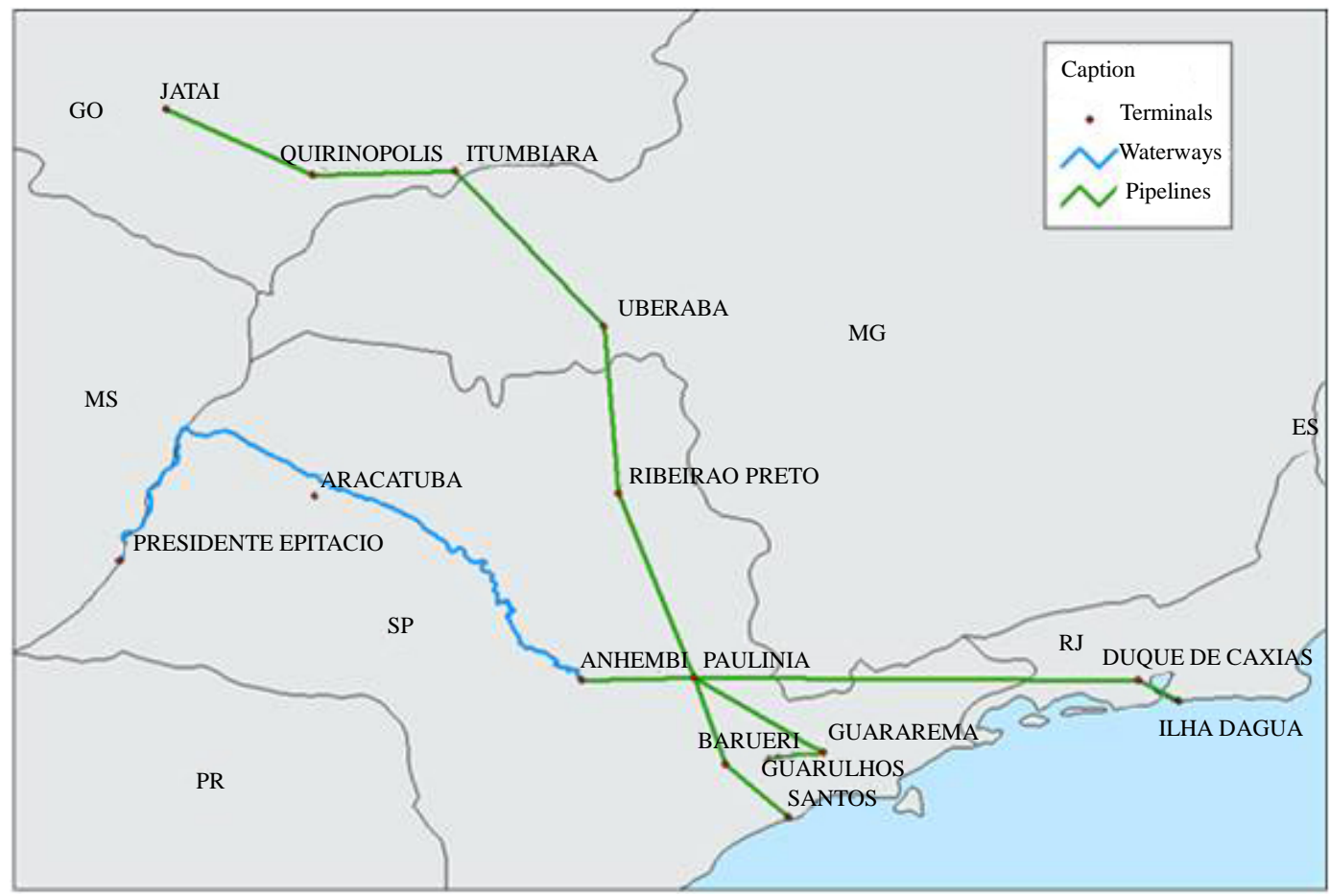

Figure 7. Prediction of the LOGUM multimodal logistics systems. Source: LOGUM LOGÍSTICA [23]. 


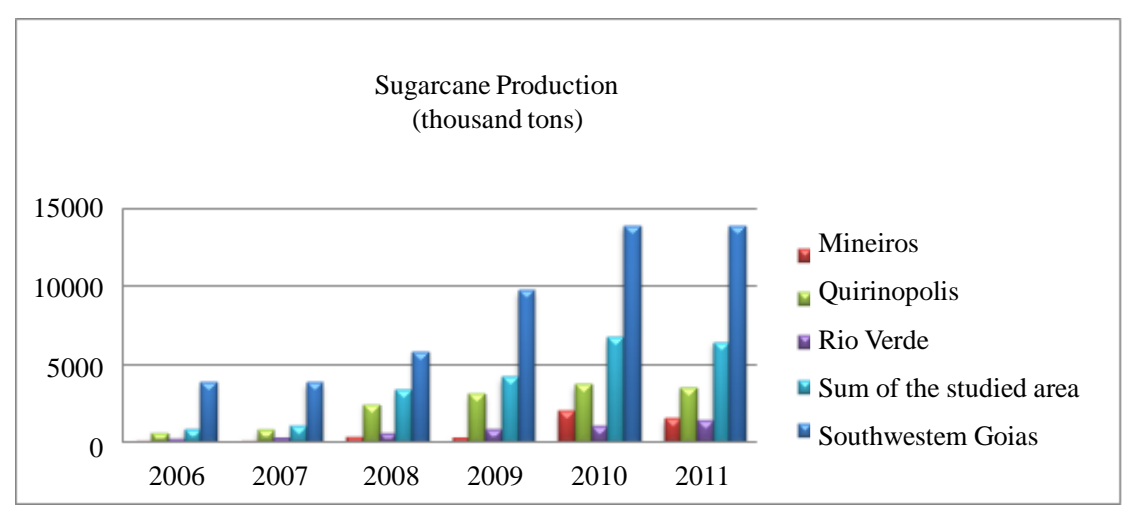

Figure 8. Sugarcane production chart. Source: IBGE [10].

time series, and especially the absence of cloud cover, which is a decisive factor in the images display for mapping.

The TM/Landsat-5 satellite has 7 spectral bands with spatial resolution of 30 meters, except for its spectral band 6, which has spatial resolution of 120 meters (http://www.dgi.inpe.br/CDSR/). Bands 3, 4 and 5 were selected to conduct the current study. After the images were acquired, they were georeferenced in ArGIS 10.1 software at the Geo-information Center of Embrapa Solos. The satellite-monitoring system information about sugarcane production —available at CanaSat (http://www.dsr.inpe.br/laf/canasat/) — was used to process and to prepare the cultivation maps in the ArGIS 10.1 software. The maps generated by Canasat were overlaid on maps generated from the Landsat images. Thus, it was possible to identify the specific areas of sugarcane cultivation in the maps. The maps corresponding to each assessed year (1985, 2004, 2010/2011) were prepared in order to comparatively observe the land use change dynamics.

\section{Results and Discussion}

Figures 9-11 show intense land use and land cover changes in the analyzed time series. Agricultural and pasture areas were expanded whereas green areas-forest, savannas and grasslands were suppressed.

It is worth emphasizing that the sugarcane culture became notable in the adopted scale just in the last analyzed period (2010/2011), despite the large area allocated for agriculture.

The sugarcane production satellite monitoring system-CanaSat—allowed comparing the sugarcane cultivation areas in the counties (Figures 12-14).

Another parameter studied at logistical level is the sugarcane plantation proximity to ethanol and sugar refineries. The maximum distance between the crop and the plant must be $40 \mathrm{~km}$ in order to preserve the sugarcane grinding features [15] (Figures 15-17).

In short, Quirinopolis and Rio Verde counties have good availability of plants within the $40 \mathrm{~km}$ indicated radius, as opposed to Mineiros County, thus demanding bigger and improved logistic alternatives.

\section{Conditions and Perspectives}

The Southwestern Goiás region as a whole is a region in socioeconomic ascent. Its production and land use dynamics intensively changed in recent years and the region attracts studies and investments for crop improvement. Mineiros, Quirinópolis and Rio Verde counties play a prominent role in the State sugar-energy scenario and they account together for almost half of the sugarcane production of all 26 counties forming the region.

The region is currently focused on the domestic market. Thus, its challenge is to improve the logistics system in order to monitor production and productivity growth, to make the product from Goiás more competitive, and to reach new markets as well as to account for the $20 \%$ to $25 \%$ increase in the gasoline ethanol content, which was approved by the government in 2013.

The State has approximately 25,000 km of highways and its investment plans were set at 3 billion Reais for transportation improvement and expansion. There are also approximately $700 \mathrm{~km}$ of railways crossing the State as well as the North-South railway-still under construction-with extension to Quirinópolis. When the railway is 
Map Showing the Land Use and Coverage in Mineiros County

1985

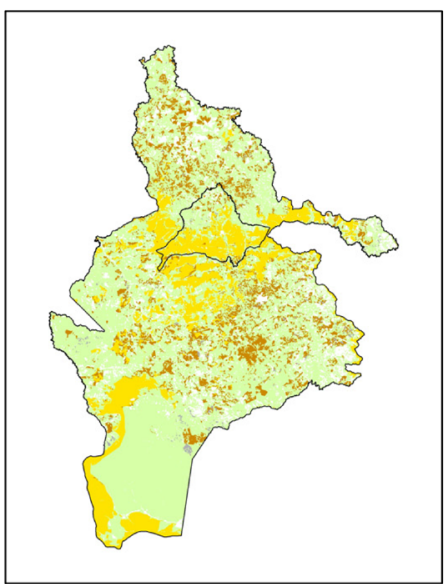

2004

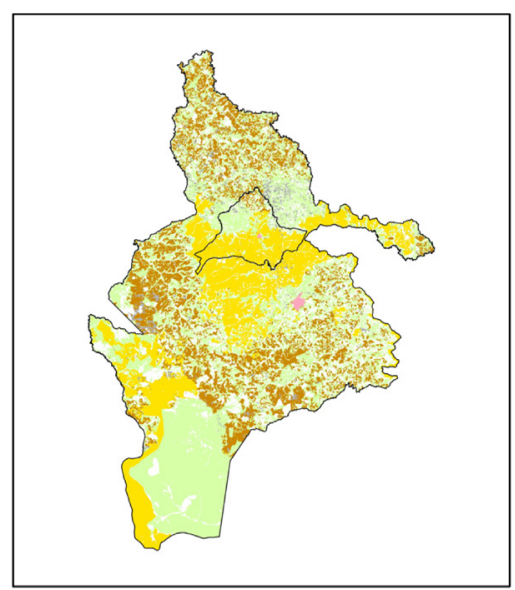

2010

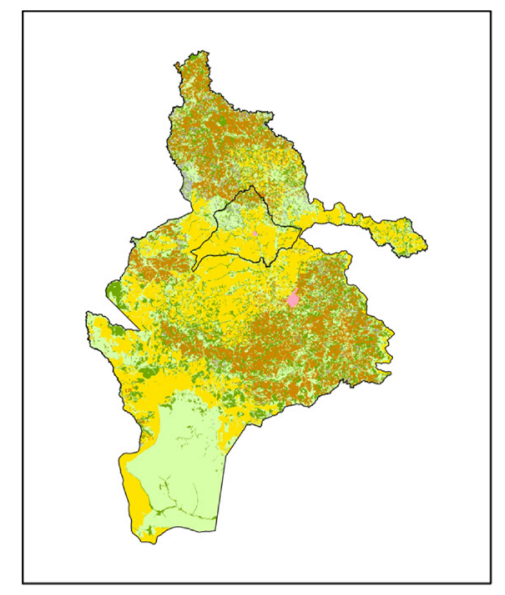

\begin{tabular}{|l|l|}
\hline Classes and Subclasses of Coverage and Land Use \\
$\mathbf{1}$ Non-agricultural urban area \\
Urban area
\end{tabular}
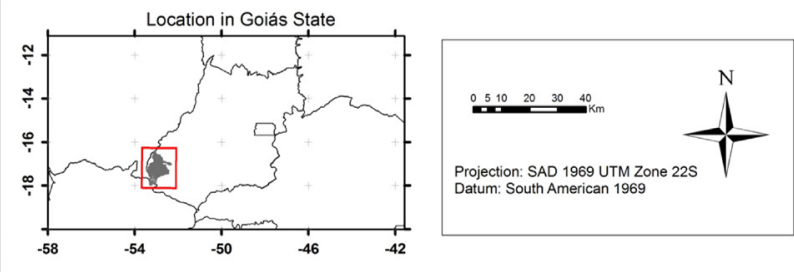

Figure 9. Map showing land use and native vegetation of Mineiros County (GO).

Map Showing Land use and coverage in Quirinópolis County

1985

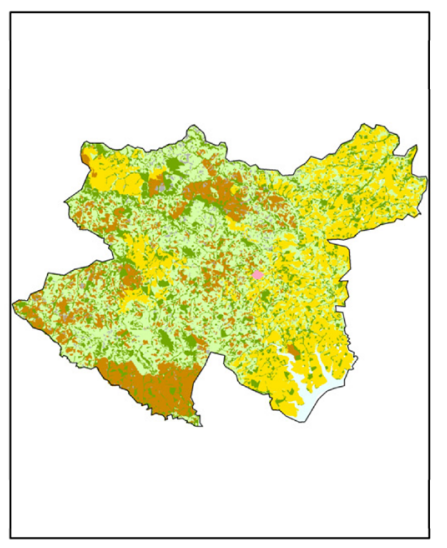

2004

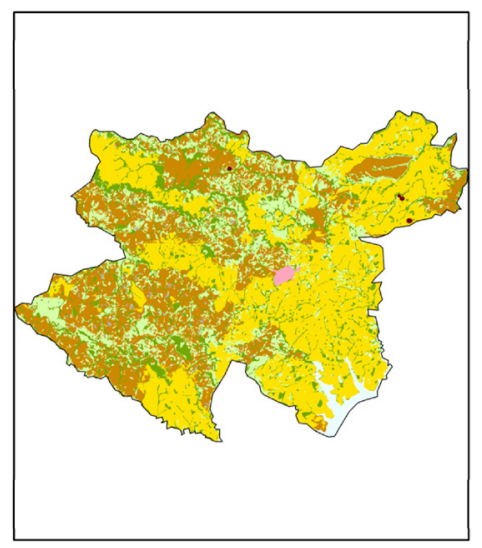

2011

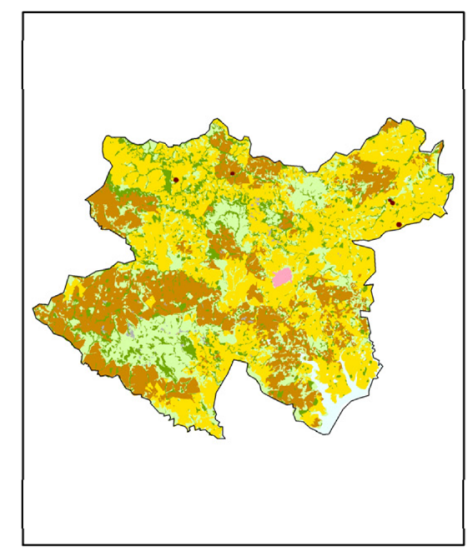

\begin{tabular}{|l|c|}
\hline \multicolumn{2}{|c|}{ Classes and Subclasses of Coverage and Land Use } \\
$\mathbf{1}$ Non-agricultural urban area & $\mathbf{3}$ Natural vegetation areas \\
Urban area & Native vegetation \\
Exposed soil & Grassland vegetation \\
$\mathbf{2}$ Agricultural urban areas & $\mathbf{4}$ Water \\
Agricultural areas & Continental water bodies \\
Pasture & $\mathbf{5}$ Other use \\
Irrigation pivot & Others \\
\hline
\end{tabular}
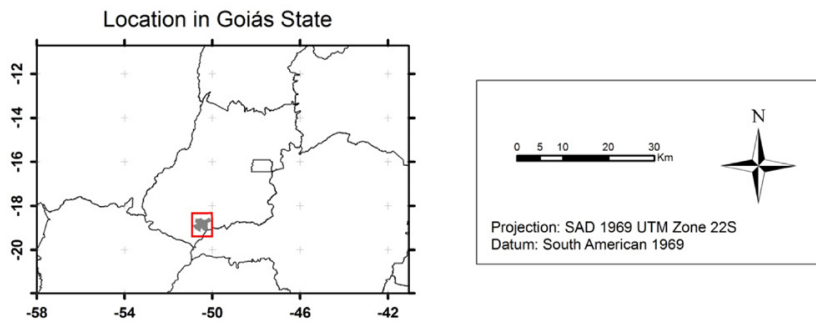

Figure 10. Map showing land use and native vegetation of Quirinópolis County (GO). 
Map Showing Land use and Coverage in Rio Verde County
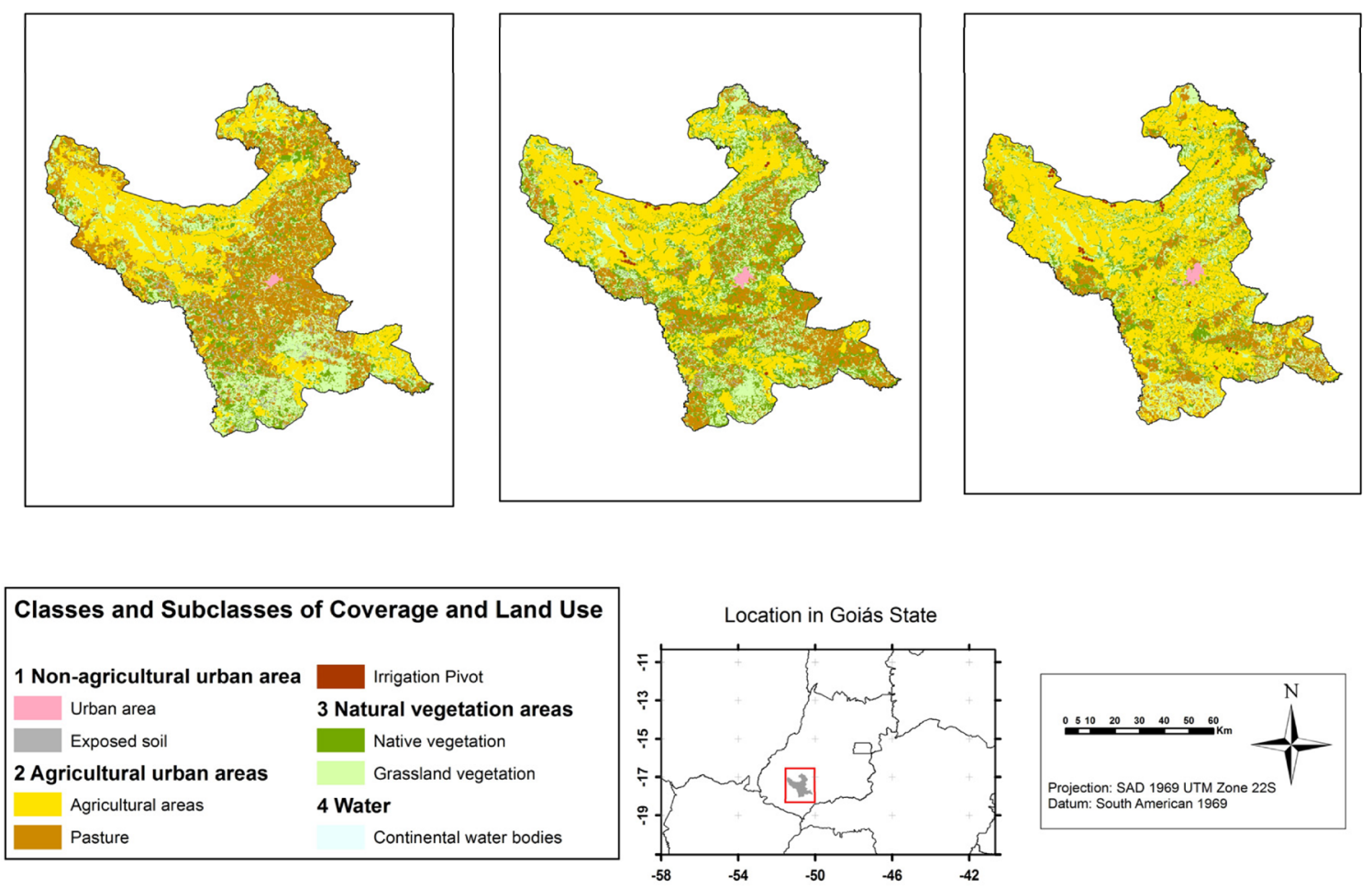

Figure 11. Map showing land use and native vegetation of Rio Verde County (GO).

Land Use and Coverage in Mineiros County in 2010

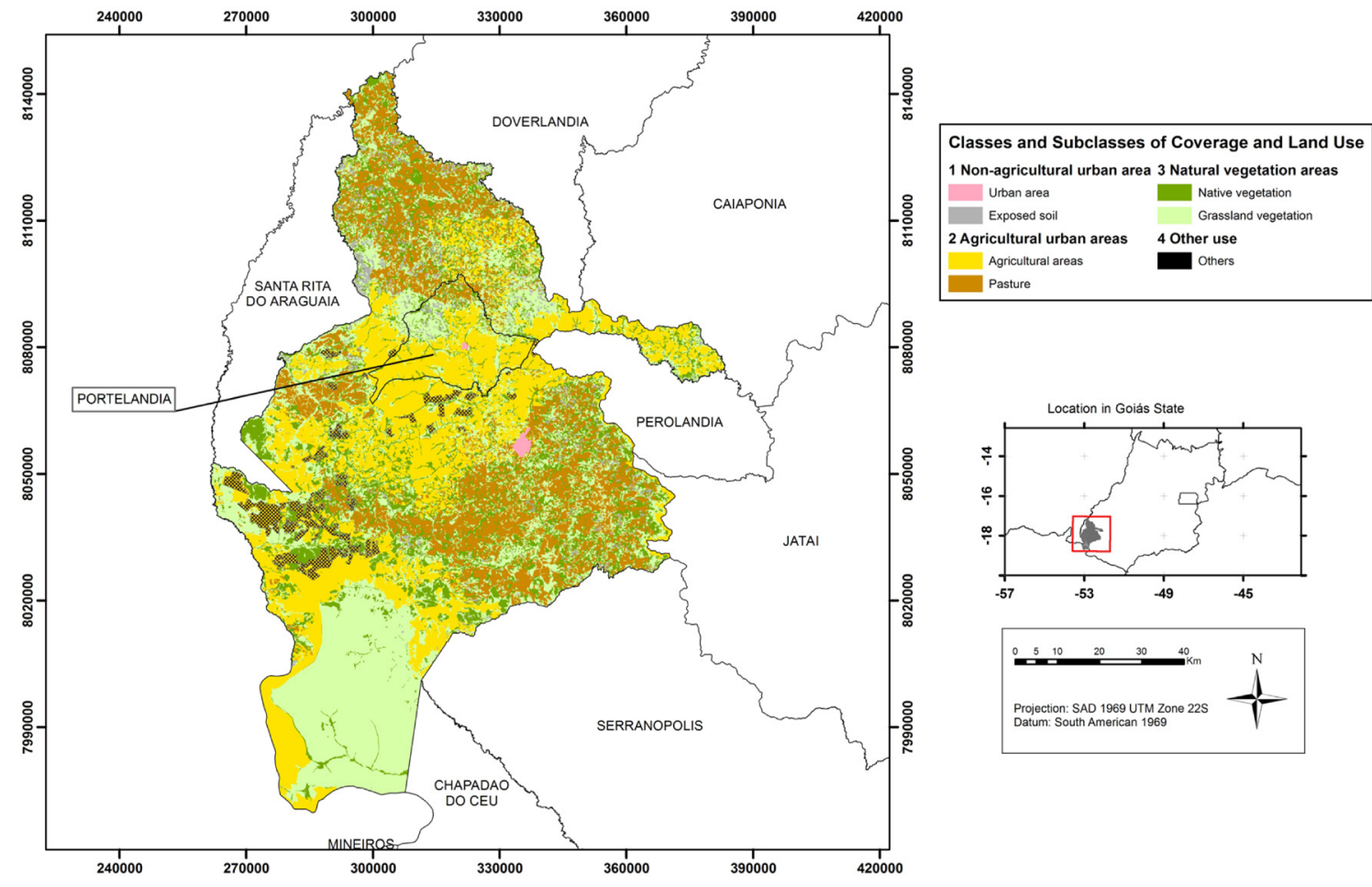

Figure 12. Map showing land use and native vegetation of Mineiros County (GO). 


\section{Land use and coverage in Quirinópolis County in 2011}

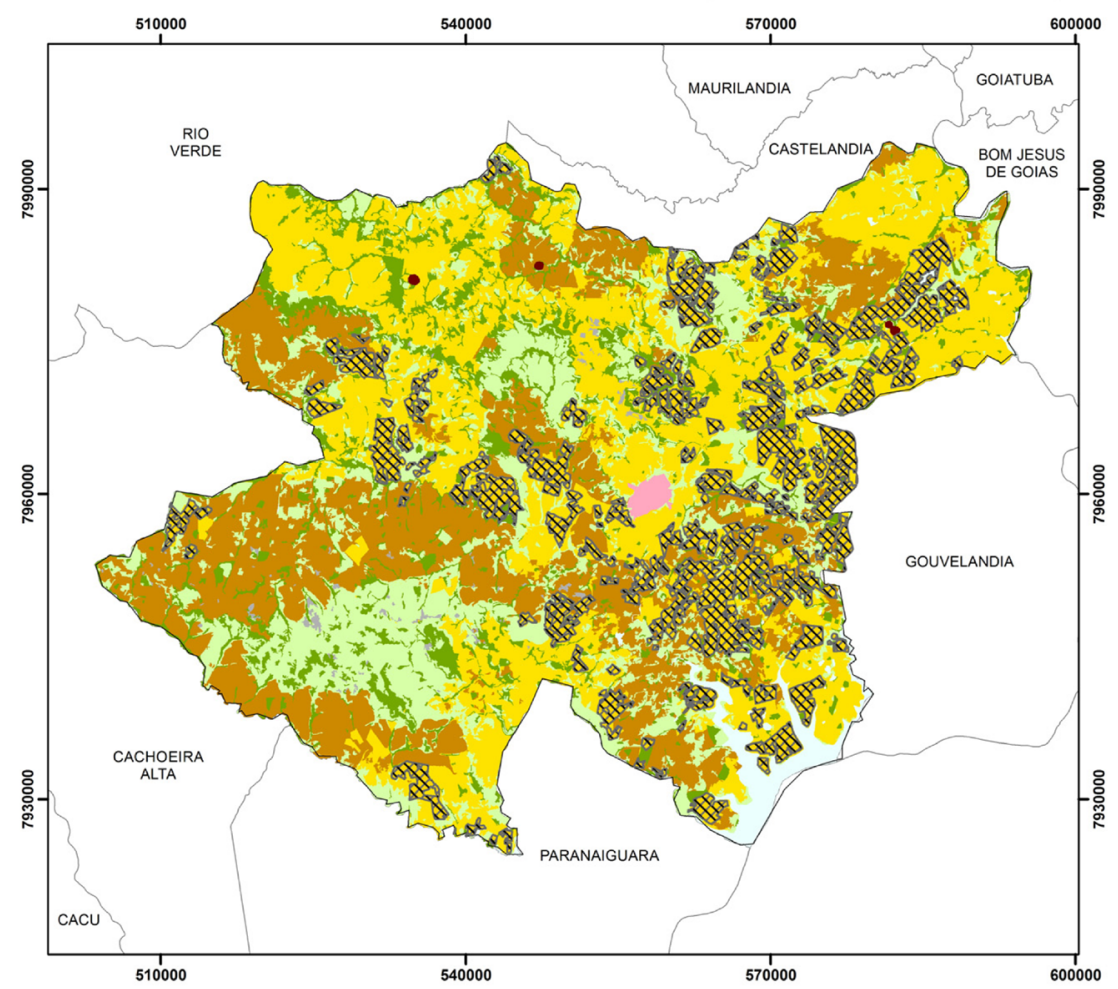

\begin{tabular}{|l|l|}
\hline Classes and Subclasses of \\
Coverage and Land Use \\
1 Non-agricultural urban area \\
Urban area \\
Exposed soil \\
2 Agricultural urban areas \\
Agricultural areas \\
Pasture \\
Irigation pivot \\
3 Natural vegetation areas \\
Native vegetation \\
Grassland vegetation \\
4 Water \\
Continental water bodies \\
5 Other use \\
Others
\end{tabular}

象

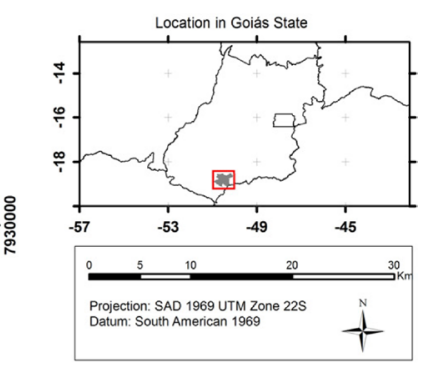

Figure 13. Map showing land use and native vegetation of Quirinópolis County (GO).

Land use and coverage in Rio Verde county in 2011
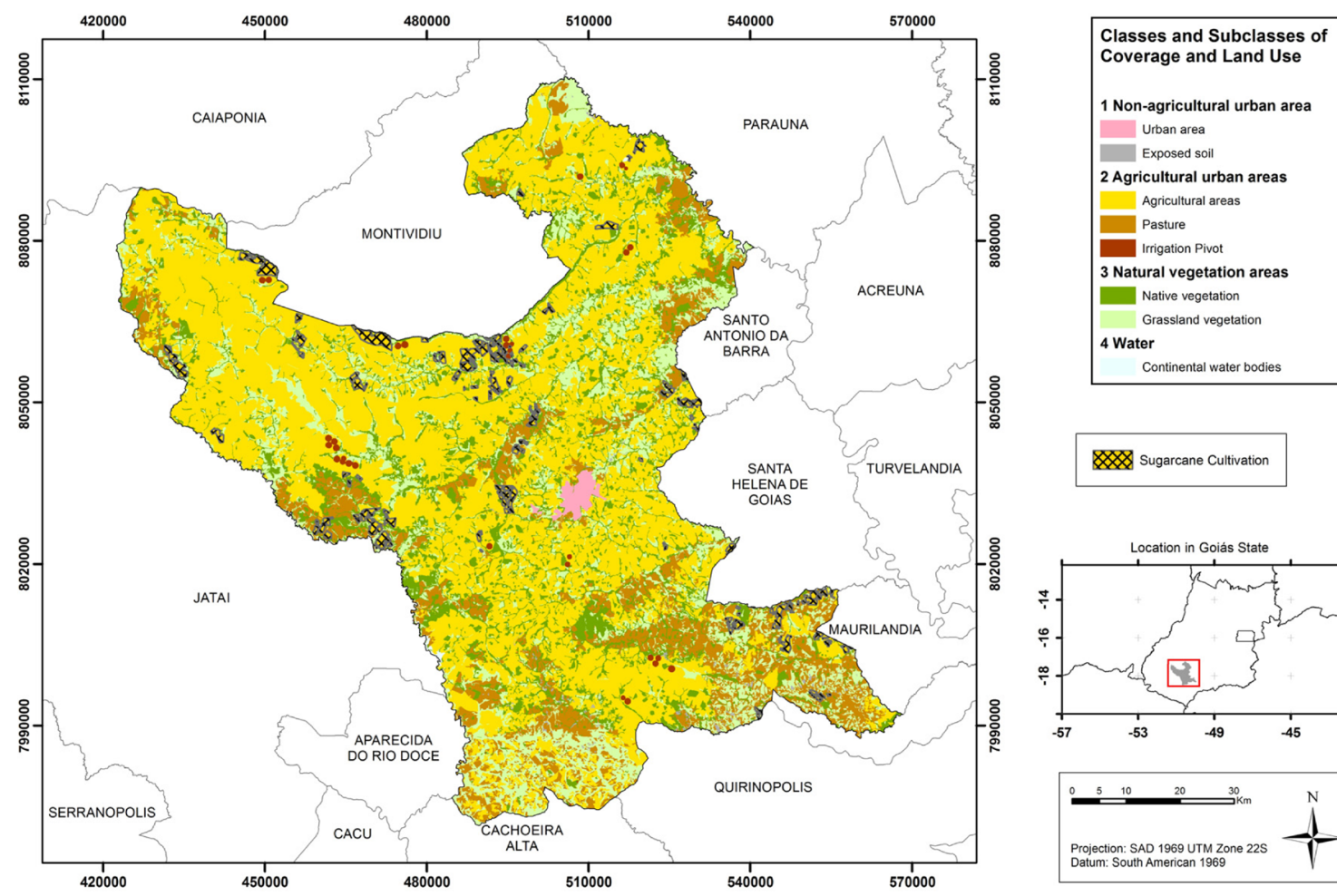

Sugarcane Cultivation
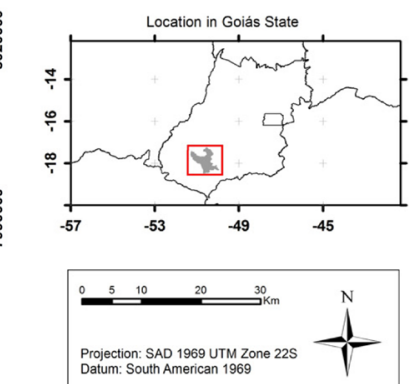

Figure 14. Map showing land use and native vegetation of Rio Verde County (GO). 


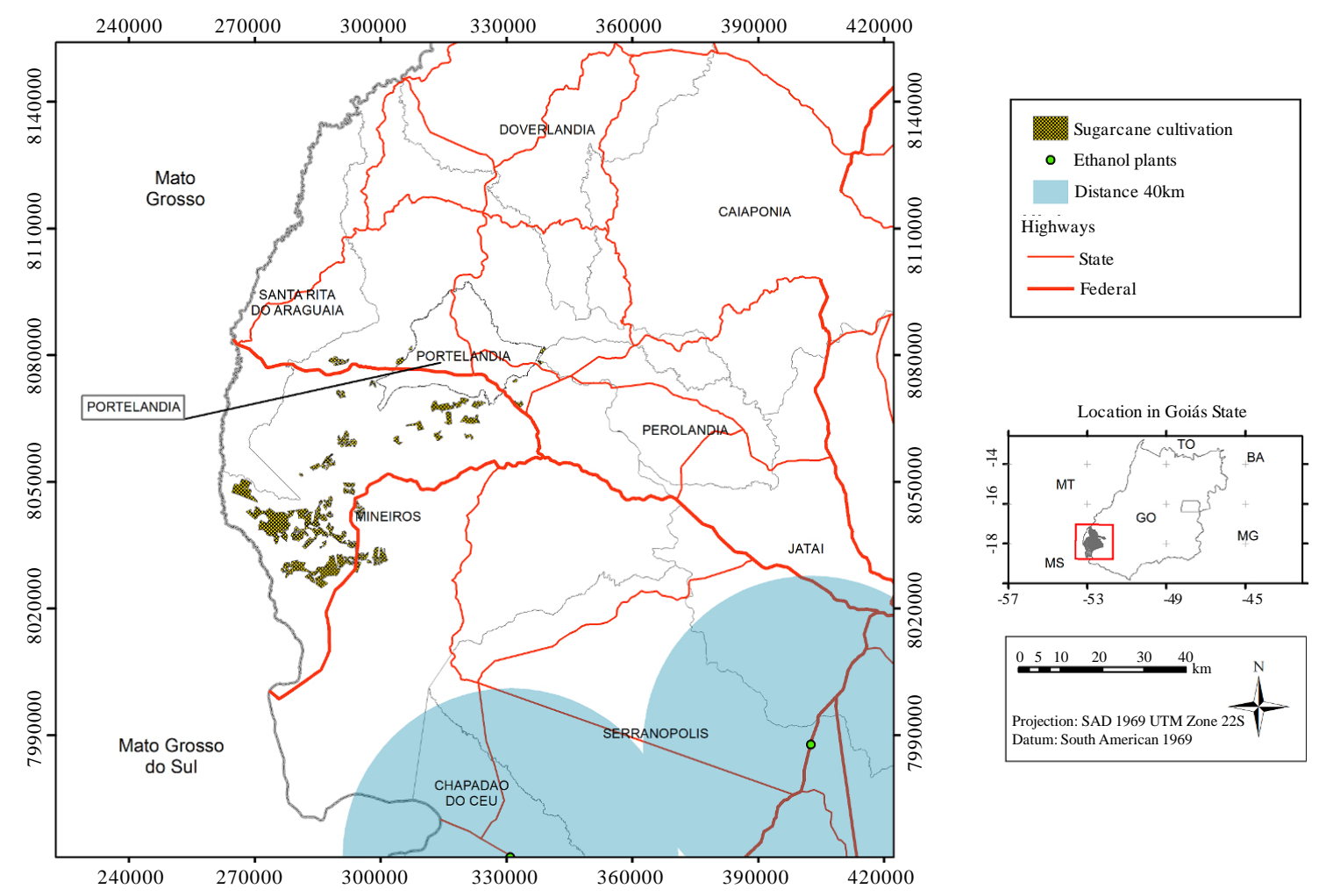

Figure 15. $40 \mathrm{~km}$ radius from the planting areas to the sugar mills in Mineiros County region (GO) in 2010. Note the great distance from the area covered by the radius.

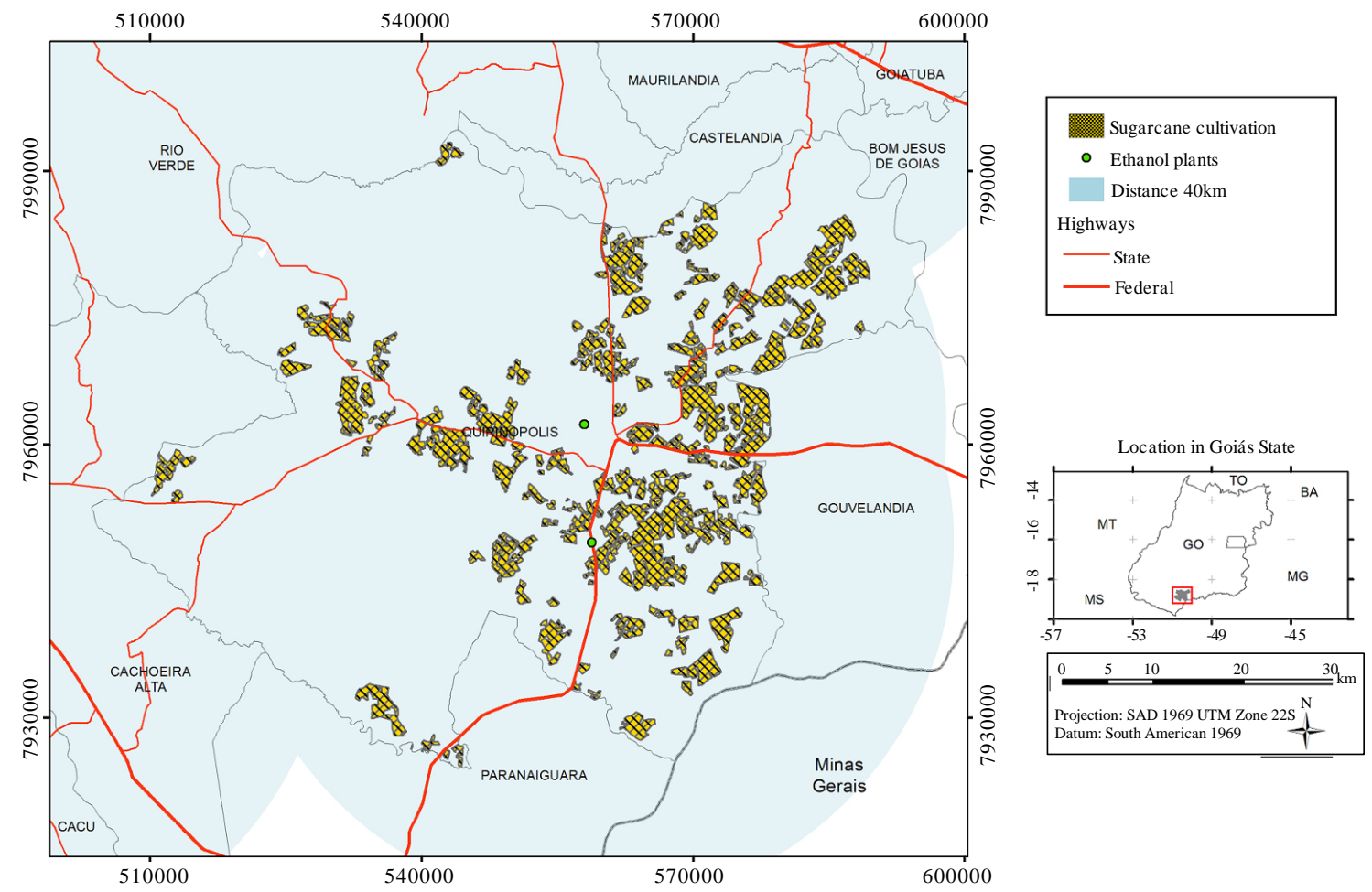

Figure 16. $40 \mathrm{~km}$ radius from the planting areas to the sugarcane plants in Quirinópolis County region (GO) in 2011. Note that the radius covers all the cultivation areas. 


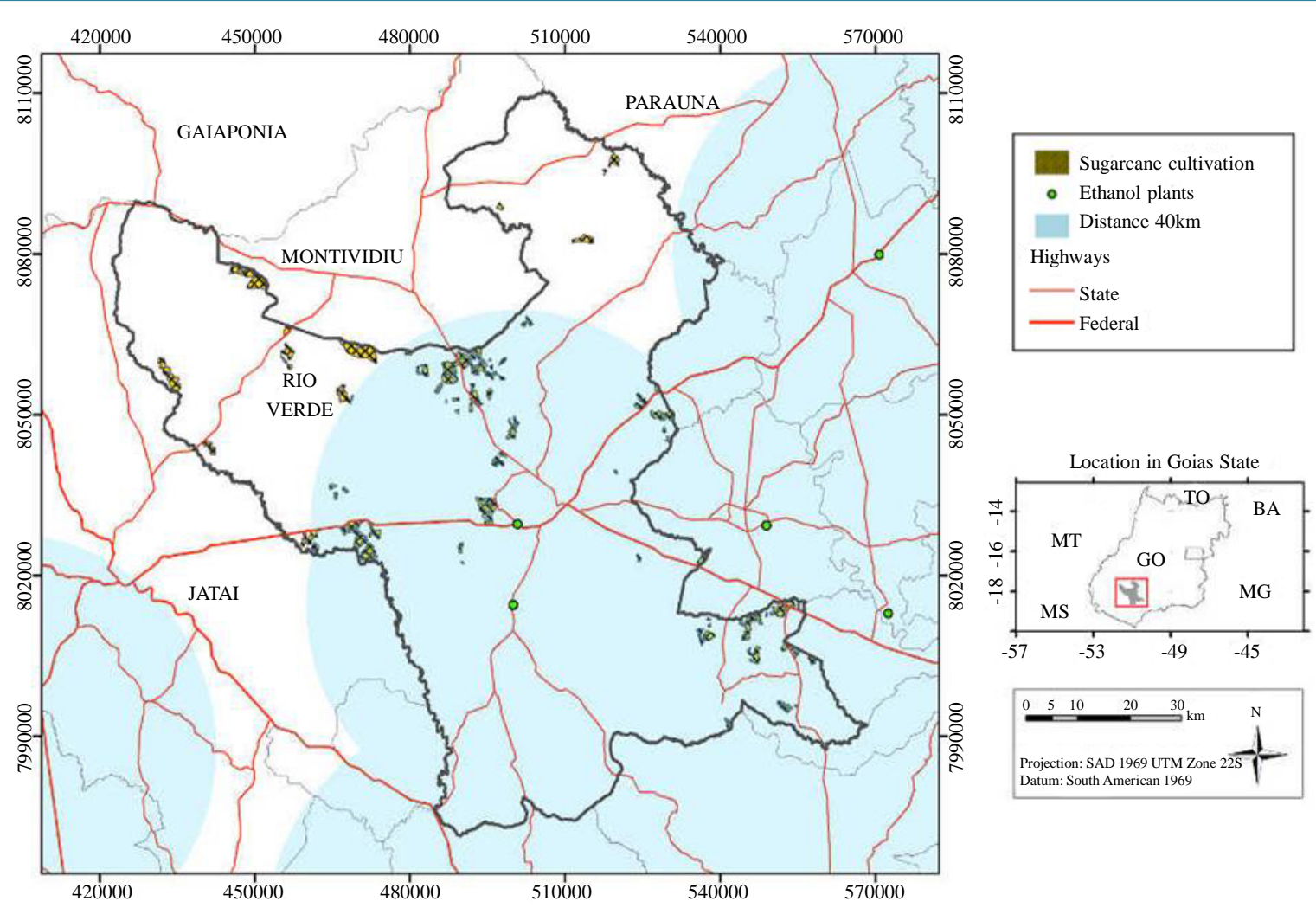

Figure 17. $40 \mathrm{~km}$ radius from the planting areas to the sugarcane plants in Rio Verde County region (GO) in 2011. Note that the radius covers most cultivation areas.

finished, it will have 1200 km extension in Goiás territory alone. Both modes are connected to São Simão waterway terminal, which, through the Paraná-Tietê waterway, is able to transport 2100 tons/hour of the grains produced in the State.

Nowadays, the production is mainly transported to the market by road, without much integration among the transportation modes. Although this mode shows higher freight costs and causes larger environmental impacts, it is a viable option because it is more agile than the other transportation modes and especially due to the possibility of the so-called "return cargo". As the name implies, return cargo is the transportation done in the reverse of the traditional sense, i.e., the lorries may provide inputs such as fertilizers, grains, fuel, among others, and return with the product. Thus, the freight becomes cheaper and more stable during the year. However, the long distance from the State to the ports, which are on the coast, makes the Goiás State’s product less competitive than that of São Paulo.

Therefore, the sugarcane production in the region will only be driven by investments in logistics infrastructure, which is already happening. The federal highways and railways concessions given to private companies were the first step to boost cargo transportation. The pipeline terminals that will go from São Paulo to Southwestern Goiás will be an excellent option for transporting ethanol. The product will be then exported or distributed throughout the Southeastern region, which is the largest consumer market in Brazil. Investments will also be applied to the waterway mode. The Tietê-Paraná waterway will receive ethanol transport terminals and it will be integrated into the pipeline system.

Investments done in infrastructure and in intermodal integration are expected to turn the Midwestern and mainly the Southwestern Goiás into large producers of sugarcane and its derivatives in order to compete with other production centers. In addition, these options could make the transportation more suitable for environmental preservation.

\section{Final Considerations}

The Southwest Goiás region is the focus of the recent and ongoing sugarcane expansion and it attracts major in- 
itiatives in infrastructure, among them, federal highways and railways concessions for private investment, the construction of pipelines connecting Goiás to Minas Gerais and to São Paulo States, and the intermodal logistics system projects for production flow.

Thus, Mineiros, Quirinópolis and Rio Verde counties became major agricultural producers in a few years and, nowadays, they were a part of the sugarcane expansion scenario, either because they were expansion targets (Quirinópolis and Mineiros) or because they limited the expansion. Mineiros is the largest among the three counties and although it has suffered negative variations in recent years, it is still a great option for sugarcane production.

Quirinópolis is the smallest among the three analyzed counties; however, it offers great attractions to producers, such as its proximity to several refineries and to São Simão waterway terminal. It also has good roads, large areas with good soils and relief for sugarcane cultivation and it is largely benefited by the projects planned for the State, thus becoming the new sugarcane center in Goiás State and in the Midwestern region.

Rio Verde has the largest agricultural area among the three counties; however, the local law limits the sugarcane plantation to only $10 \%$ of the agricultural real estates in order to avoid developing monoculture system and losing the diversity and strong agribusiness set in the county.

The high investments in transportation infrastructure are expected to allow producers to also have the necessary support to keep the increasing pace, but in a sustainable way, thus responding to the expectations put on the region.

\section{References}

[1] Silva, A.A. and Miziara, F. (2011) Avanço do setor sucroalcooleiro e expansão da fronteira agrícola em Goiás. Pesquisa Agropecuária Tropical, Goiânia, 41, 399-407. http://dx.doi.org/10.5216/pat.v41i3.11054

[2] Rudorff, B.F.T., Aguiar, D.A., Silva, W.F., Sugawara, L.M., Adami, M. and Moreira, M.A. (2010) Studies on the Rapid Expansion of Sugarcane for Ethanol Production in São Paulo State (Brazil) Using Landsat Data. Remote Sensing, 2, 1057-1076. http://dx.doi.org/10.3390/rs2041057

[3] Silva, A.A. and Castro, S.S. (2011) Dinâmica de uso da terra e expansão da cana-de-açúcar entre osanos de 2004 a 2010, namicrorregião de Quirinópolis, Goiás In: Transformações no Cerrado: Processo, consumo e natureza, 1a. Ed. Ed. da PUC Goiás, Goiânia, 155-188.

[4] Queiroz, S.T.P. (2008) Usinas de Álcool—Fatores Influentes no Processo de Escolha da Localização de Novas Unidades. UNB, Brasília.

[5] Castro, S.S., Abdala, K., Silva, A.A. and Borges, V. (2010) A expansão da cana-de-açúcar no cerrado e no estado de Goiás: Elementos para uma análise espacial do processo. Boletim Goiano de Geografia (Online), 30, 171-191.

[6] Florenzano, T.G. (2007) Iniciação em sensoriamento remoto. 2ª edição de imagens de satélite para estudos ambientais. Oficina de Textos, São Paulo.

[7] ANP. Agência Nacional de Pétróleo (2015). http://anp.gov.br

[8] UNICA. União da Indústria de Cana-de-açúcar (2015). http://unicadata.com.br

[9] UNICA/UNICAMP (2005) Estudo sobre as possibilidades e impactos da produção de grandes quantidades de etanol visando à substituição parcial da gasolina no mundo. FUNCAMP/CGE-Centro de Gestão e Estudos Estratégicos. Relatório Final.

[10] IBGE. Levantamento Sistemático da ProduçãoAgrícola (2014).

[11] MAPA. Ministério da Agricultura, Pecuária e Abastecimento (2010) Anuário Estatístico da Agroenergia.

[12] MDIC. Ministério do Desenvolvimento, Indústria e Comércio Exterior (2015).

[13] Mitsunani, C. (2010) A Logística do Etanol de Cana-de-açúcar no Brasil: Condicionantes e Perspectivas. USP, São Paulo.

[14] Moura, R.A. (2003) Atualidades na Logística. IMAM, São Paulo.

[15] Nunes, P.B. (2010) Caracterização Logística do Sistema Agroindustrial da Cana-de-Açúcar do Centro-Sul do Brasil. Piracicaba. http://esalqlog.esalq.usp.br/files/biblioteca/arquivo3744.PDF

[16] Setten, A. (2010) Mecanismos de redução de custos logísticos de exportação. In: Seminário Internacional em Logística Agroindustrial, São Paulo.

[17] Oliva, J.A.B.de. (2010) Custo Brasil: infraestrutura portuária transporte hidroviário interior como solução logística e ambiental. In: Seminário Internacional em Logística Agroindustrial-USP, São Paulo. 
[18] Da Silva, W.R.Z. (2011) Estratégia Competitiva e Logística: As Diferenças Entre Goiás e Mato Grosso no Setor Sucroalcooleiro. UFRJ, Rio de Janeiro. http://www.nuclamb.geografia.ufrj.br/publicacoes/arquivos/singa_wanderson.pdf

[19] Da Silva, W. (2012) As Possibilidades Logísticas Para o Escoamento de Etanol em Goiás. UFRJ. Rio de Janeiro.

[20] MT. Ministério dos Transportes (2015). http://www.transportes.gov.br/

[21] Barbalho, M.G.daS., Silva, A.A. and Castro, S.S.de. (2013) A expansão da área de cultivo da cana-de-açúcar na região sul do estado de Goiás de 2001 a 2011. Revista Brasileira de Ciências Ambientais, v 29, São Paulo.

[22] Nassar, A.M., Rudorff, B.F.T., Antoniazzi, L.B., Aguiar, D.A., Bacchi, M.R.P. and Adami, M. (2008) Prospects of the Sugarcane Expansion in Brazil: Impacts on Direct and Indirect Land Use Changes. In: Zuurbier, P. and Vooren, J.V. (Org.), Sugarcaneethanol: Contributions to Climate Change Mitigation and the Environment, Wageningen Academic Publishers, Wageningen, 63-93.

[23] LOGUM LOGÍSTICA. Logística de etanol (2015). http://www.logum.com.br/php/index.php 